\title{
Evaluation of Genotoxic and Lipid Peroxidation Effect of Cadmium in Developing Chick Embryos
}

Meena Bai M, Divya K, Haseena Bhanu SK, Sailaja G, Sandhya D and Thyagaraju K*

Department of Biochemistry, Sri Venkateswara University, Tirupati, Andhra Pradesh, India

\begin{abstract}
Our study was aimed to evaluate the effects of cadmium on chick embryo liver tissue. $10^{\text {th }}, 11^{\text {th }}$ and $12^{\text {th }}$ day old Bobcock strain chick embryos were exposed to cadmium individually, by in ovo treatment. These concentrations 40 , $50,60 \mu \mathrm{g}$ of Cadmium at different time intervals i.e., 24, 48, $72 \mathrm{hr}$, were administered to developing chick embryo. On the $13^{\text {th }}$ study day, blood and the liver tissues collected were tested for genotoxic and lipid peroxidation assays. In this study, the presence of micronucleated erythrocytes and also various abnormal cells in the blood smear indicated the role of cadmium-induced genotoxicity. Current findings showed that frequency of micronucleated erythrocytes increased with increased doses of cadmium and time interval. MDA levels were high in cadmium exposed group compared to control group. These findings suggest the genotoxic and an oxidative stress mechanism in cadmium-induced liver tissue enhances damage.
\end{abstract}

Keywords: Cadmium; Chick embryo liver; Lipid peroxidation assay; Genotoxicity; Micronucleus test; in ovo injection; Oxidative stress

\section{Abbreviations}

Cd: Cadmium; ROS: Reactive Oxygen Species; GSH: Reduced Glutathione; PUFA: Polyunsaturated Fatty Acid; MDA: Malondialdehyde; MN: Micronuclei; $\mu \mathrm{l}$ : Micro liter; $\mu \mathrm{g}$ : Micro gram; min: Minute; mg: Milligram; PCE: Polychromatic Erythrocytes; d: Day; NCE: Normochromatic Erythrocytes; mn-PCE: Micronucleated Polychromatic Erythrocytes; mn-NCE: Micronucleated Normochromatic Erythrocytes; KCl: Potassium Chloride; SDS: Sodium Dodecyl Sulphate; TBA: Thiobarbituric Acid; ml: Milliliter; rpm: Revolutions Per Minute; nm: Nanometer; BSA: Bovine Serum Albumin; DNA: Deoxyribonucleic Acid; g: Gram/gravity; SD: Standard Deviation; h: Hour; D: Dacryocyte or Tear Drop Cell; T: Thrombocyte; PN: Primitive NCE with Chromosomal Abberance; MNE: Micronuclei Erythrocyte; nmol: Nanomoles

\section{Introduction}

An earth's crust natural element, cadmium (Cd), is usually found as a mineral in combination with other elements such as oxygen, chlorine, or sulfur. Over the past two centuries, anthropogenic and industrial activities have led to high emissions of $\mathrm{Cd}$ into the environment at concentrations significantly exceeding those originating from natural sources $[1,2]$. Since Cd is not degraded, the risk of environmental exposure is constantly increased because of accumulation and spread via the food chain $[3,4]$. At the cellular level, Cd induces oxidative stress in many organisms $[5,6]$, which might result in physiological damage to organs such as kidneys, liver, lung, pancreas, testes, placenta and bone [7-9].

Cadmium is an inorganic toxicant of great environmental and occupational concern, which was classified as a human carcinogen in 1993. It is one of the most toxic pollutants in environment $[10,11]$ as reported by WHO. When cadmium accumulates in blood, it affects the renal cortex and causes renal failure, and also lead to some cardiovascular problems under certain industrial growth conditions $[12,13]$. Liver and kidney damage due to acute or chronic cadmium exposure have suggested some mechanisms for cadmium toxicity. In cellular level, cadmium depletes glutathione and protein-bound sulfhydryl groups, resulting in enhanced production of reactive oxygen species (ROS) such as superoxide ion, hydroxyl radicals, and hydrogen peroxide [14]. Because of production of ROS which serve as electrophile may bind to an abundant nucleophile i.e. DNA after the consumption of limited quantity of GSH [15]. These ROS also lead to propagation of lipid peroxidation [16], enhanced excretion of urinary lipid metabolites [17], modulation of intracellular oxidized states, DNA and cell membrane damages [18], altered gene expression [19] and apoptosis [20].

Lipid peroxides formed due to the action of oxygen free radicals on polyunsaturated fatty acid (PUFA) are known to occur in all the biological membranes [21]. As a result various products formed are lipid peroxides, hydroperoxides, epoxy alcohols, short chain dicarboxylic acids, malondialdehydes (MDA), ethane, pentane, and 4-OH alkenals. MDA and 4-OH alkenals are the most extensively studied LPO products [22]. MDA, a bifunctional aldehyde easily reacts with proteins and thus inactivates many enzymes and it is proven indicators of oxidative stress [23]. Lipid peroxides also reacts with various macromolecules for inactivating and resulting in cell death [20].

The effects of Cd on antioxidative capacity are dual: on one hand, $\mathrm{Cd}$ can induce oxidative stress via the inhibition of antioxidants, and on the other it activates several antioxidative components as a result of a disturbed redox balance to consecutively induce signal transduction cascade [24]. The mechanism of cadmium-mediated acute hepatotoxicity has been the subject of numerous investigations and sufficient evidence has emerged to reveal reasonable mechanisms for the toxic process, although some unexplained aspects still persist. Acute hepatotoxicity involves two pathways: one for the initial injury produced by direct effects of cadmium and the other for the subsequent injury produced by inflammation. Primary injury appears

*Corresponding author: Professor Thyagaraju K, Department of Biochemistry, Sri Venkateswara University, Tirupati, 517502, Andhra Pradesh, India, Tel: 91 9849063289; E-mail: thyagarajuk_1999@yahoo.com

Received April 09, 2014; Accepted July 28, 2014; Published July 31, 2014

Citation: Meena Bai M, Divya K, Haseena Bhanu SK, Sailaja G, Sandhya D, et al. (2014) Evaluation of Genotoxic and Lipid Peroxidation Effect of Cadmium in Developing Chick Embryos. J Environ Anal Toxicol 4: 238. doi: 10.4172/2161-0525.1000238

Copyright: $\odot 2014$ Meena Bai M, et al. This is an open-access article distributed under the terms of the Creative Commons Attribution License, which permits unrestricted use, distribution, and reproduction in any medium, provided the original author and source are credited. 
to be caused by the binding of $\mathrm{Cd}^{2+}$ to sulfhydryl groups on critical molecules in mitochondria [25]. Thiol group inactivation causes stress, mitochondrial permeability transition and mitochondrial dysfunction [17]. Secondary injury from acute cadmium exposure is assumed to originate from the activation of Kupffer cells and a cascade of events involving several types of liver cells and a large number of inflammatory and cytotoxic mediators [26].

The avian embryo is able to detoxify and excrete xenobiotics into the allantoic sac, where the products of the kidneys accumulate [27]. Due to the complex metabolic competence, the chick embryo, therefore, serves as a model system for genotoxicity testing, owing to its capability of undergoing metabolic activation and deactivation of xenobiotics [28].

Micronuclei (MN) test is widely accepted and used for testing genotoxicity and it is the best tool for study of chromosomal malformation [29]. Micronuclei are cytoplasmic chromatin-containing bodies that appear in the cell like a small satellite nucleus around the cell nucleus, due to chromosome fragments or entire chromosomes that are not incorporated into the main nucleus after cell division. The $\mathrm{MN}$ assay provides a simple and rapid indirect measure of induced structural and numerical chromosomal aberration and is scientifically accepted by international authorities like the Organization for Economic Cooperation and Development, International Conference on Harmonization, and European Union [30].

Micronuclei in cells formed due to xenobiotics are considered as biomarkers of damage to DNA [31]. The formation of $\mathrm{MN}$ is extensively used in molecular epidemiology as a biomarker of chromosomal damage, genome instability, and eventually of cancer risk. The occurrence of $\mathrm{MN}$ represents an integrated response to chromosome-instability phenotypes and altered cellular viabilities induced by genetic defects and/or exogenous exposures to genotoxic agents [32]. Accordingly, the MN test evaluates the frequency of $\mathrm{MN}$ formation in a proliferating cell population in vitro [33,34], as well as in vivo and in various tissues in ovary, bone marrow, peripheral blood, liver, and in fetal cells of rodents and humans [35,36]. Hence, owing to their precision in analysis and widely accepted application in genotoxicity testing, the MN was performed in the present study to evaluate the genotoxic potential of the selected heavy metal, Cadmium in developing embryos for evaluation of damage either at cell or chromosomal level.

\section{Materials and Methods}

\section{Chemicals}

Cadmium chloride (analytical standard), supplied by SD fine chemicals Ltd (India), was used for the study. Saline was used for preparing suspensions of $\mathrm{Cd}$ (volume of injection was $100 \mu \mathrm{l}$ per egg). Cyclophosphamide was purchased from Sigma Chemical Co., St. Louis, U.S.A. Giemsa and May-Grunwald stains were purchased from Hi Media laboratories, Mumbai, India. All other chemicals used were of analytical grade.

\section{Egg procurement, in-ovo injections, and incubation}

Fertile Bobcock strain eggs procured from the Sri Venkateswara Veterinary University, Tirupati and Sri Balaji hatcheries, Chittoor, Andhra Pradesh, India were administered with 40, 50 and $60 \mu \mathrm{g}$ of Cd/ egg, separately with saline as vehicle. The injection volume was $100 \mu \mathrm{l} /$ egg according to the method of Blankenship [37]. The eggs (six of each) were incubated with their broad ends up in an incubator. The day of incubation was considered as day one. The eggs were rotated for every $1 \mathrm{hr}$ and were examined through the Candler every day for the proper growth and viability. During all experiments, the live embryos were maintained at $37.5 \pm 0.5^{\circ} \mathrm{C}$ and a humidity of $70-75 \%$, except for brief intervals (60-120 seconds) required during the different treatment conditions. During this interval embryos have experienced ambient room temperature $\left(29-30^{\circ} \mathrm{C}\right)$. The eggs were incubated in triplicates for all these doses to achieve best results.

\section{Egg treatment}

The egg shell was opened at the blunt end at the top to obtain access to the air cell, where the respective test substance $(100 \mu \mathrm{l})$ was injected directly on to the inner shell membrane. Covering the hole by wax could ensure the embryos vitality for the remaining time until blood sampling and dissection. Chick embryonic liver was collected on d 13 after $24 \mathrm{hrs}$ (d12), $48 \mathrm{hrs}$ (d11) and $72 \mathrm{hrs}$ (d10) initial administration of the test substance. The liver of $13^{\text {th }}$ day was dissected out, weighed and washed using chilled saline solution since all organs are developed in this day. Tissue was minced and homogenized $(10 \% \mathrm{w} / \mathrm{v})$ in appropriate buffer (pH7.4) and centrifuged (3000 g for $10 \mathrm{~min})$. The resulting clear supernatant was used for following antioxidant assays.

\section{Blood Sampling}

At d13 blood was taken after $24 \mathrm{hrs}$ (d12), $48 \mathrm{hrs}$ (d11) and $72 \mathrm{hrs}$ (d10) initial administration of the test substance. Peripheral blood was collected by incising blood vessel of the peripheral circulatory system of the chorioallantoic membrane. $10 \mu$ of the obtained blood was spread out on slides immediately after blood sampling following the method of Wolf and Luepke [38].

\section{Micronucleus (MN) test}

The test was performed according to the method of Chaubey et al. [39]. Six embryos each were studied under different concentrations of cadmium at different time intervals. Positive controls have received $0.05 \mathrm{mg}$ of cyclophosphamide in saline. Negative controls have received the same volume of saline. Blood samples were collected from one of the chorioallantoic blood vessel of 13-day-old chick embryos, smears prepared and stained using May-Grunwald, rinsed thrice in distilled water followed by staining with diluted Giemsa for $10 \mathrm{~min}$, and rinsed in distilled water thoroughly. The slides were dried, cleared for $5 \mathrm{~min}$ in xylene, and mounted. The slides were observed under the Olympus BX60 microscope at 100x and 40x magnification. Nearly 1000 cells were observed at random for each slide and approximately 6000 cells were studied under each group. The identification of polychromatic erythrocytes (PCE) and normochromatic erythrocytes (NCE) was based on the criteria described by Wolf and Luepke [38]. The PCE are round, large cells with round nuclei, and stained blue, whereas the NCE are oval in shape and stained pink. The total percent of micronucleated polychromatic erythrocytes (mn-PCE) and micronucleated normochromatic erythrocytes (mn-NCE), as well as the PCE: NCE ratios were calculated in controls and Cd-treated groups. For classifying the different abnormal cell morphologies, the classification scheme was followed of Lucas and Jamroz [40].

\section{Determination of lipid peroxidation (LPO) and protein}

LPO was assessed by measuring malondialdehyde (MDA) formation. Lipid peroxidation, on consequence of oxidative stress, in the liver was estimated colorimetrically in terms of MDA levels as described by Okhawa [41]. MDA content was expressed as nmol per $\mathrm{mg}$ of soluble cell proteins. 
Ten per cent of tissue homogenate was prepared in $1.15 \%$ of $\mathrm{KCl}$ for lipid peroxidation. To $0.1 \mathrm{ml}$ of the tissue homogenate, added 0.2 $\mathrm{ml}$ of $8.1 \%$ SDS and $1.5 \mathrm{ml}$ of $0.8 \%$ TBA. The total volume was made up to $4 \mathrm{ml}$ with distilled water and the tubes were kept at $95^{\circ} \mathrm{C}$ for $60 \mathrm{~min}$, and then cooled. To this added $1 \mathrm{ml}$ of distilled water along with $5 \mathrm{ml}$ of $\mathrm{n}$-butanol-pyridine mixture $(15: 1 \mathrm{v} / \mathrm{v})$ and the contents were mixed vigorously. Then the tubes were centrifuged at $4000 \mathrm{rpm}$ for 10 minutes and the color of the organic layer was measured at $532 \mathrm{~nm}$. A standard curve was plotted taking 1, 1, 3, 3-tetraethoxy propane as standard and the values of the samples were obtained from the standard curve. The protein was determined according to the method of Lowry et al., using BSA as standard [42].

\section{Statistical analysis}

All values were expressed as mean \pm SD for six eggs $(n=6)$ in each group for an average of triplicates. Significant differences between the groups were determined with SPSS 10.0 software by performing one-way ANOVA. The threshold of statistical significance was set at $\mathrm{p} \leq 0.05$ (Table 1 ).

\section{Results}

\section{In vivo $\mathrm{MN}$ assay}

Erythrocytes of control eggs of $13^{\text {th }}$ day were oval shaped and uniform in size with a single normal nucleus and showed no abnormalities in their morphology. The PCE/NCE ratio was also in normal range. The blood smears of $60 \mu \mathrm{g} / \mathrm{egg}$ Cd-treated embryos presented highest frequency of micronucleated cells, compared with $50 \mu \mathrm{g} / \mathrm{egg}$ and $40 \mu \mathrm{g} / \mathrm{egg}$ Cd-treated embryos. The embryos which received $60 \mu \mathrm{g} / \mathrm{egg}$ of $\mathrm{Cd}$ were found to have markedly higher numbers of mnPCE and mnNCE. The total number of the micronucleated erythrocytes also showed a significant increase with increasing concentrations of cadmium at different time intervals. Apart from the micronucleated erythrocytes, blood smears of $60 \mu \mathrm{g} / \mathrm{egg}, 50 \mu \mathrm{g} / \mathrm{egg}$ and $40 \mu \mathrm{g} / \mathrm{egg}$ Cd-treated embryos showed various abnormal cells such as dacryocytes (tear drop cells), squashed nuclei, nuclear segmentation, and abnormal erythrocytes (Figures 1 and 2).

\section{Lipid peroxidation induction by $\mathrm{Cd}$}

Figure 3 and Table 2 were illustrated an effect of Cadmium chloride on lipid peroxidation in liver of $\mathrm{d} 13$ chick embryo. MDA contents of Cadmium treated hepatic cells were significantly higher than those of the untreated cells. The MDA levels were significantly $(p<0.05)$ increased in treated liver in a dose dependent manner. The maximum percentage of induction was seen in $60 \mu \mathrm{g} / \mathrm{egg} \mathrm{Cd}$ treatment compared to controls. In $60 \mu \mathrm{g} / \mathrm{egg}$ Cd treated embryos $1.41,1.60$ and 1.86 fold increase in the induction of MDA levels in 24, 48 and $72 \mathrm{hrs}$ treatment, was observed. The MDA contents enhanced along with the increase of incubation time and Cd concentration, which showed a dose and time-dependent pattern.

\section{Discussion}

Most of the erythrocytes observed in the embryos are yolk sac origin, which is the most metabolically active tissue [27]. In chick embryo it was reported earlier that the spleen is not a functional organ at the incubation of $11^{\text {th }}$ day [43]. So the MN formed in erythrocytes, cells accumulate more in blood since spleen is yet not functional to clear them from blood. The treatment of $\mathrm{Cd}$ evokes the formation of mn-erythrocytes and the actual numbers affected are observed to be without aberrance [44]. Therefore the 13 day-old embryo, which carries mature as well as other developing stages, of the erythroid series the embryonic treatment with $40,50,60 \mu \mathrm{g} \mathrm{Cd} / \mathrm{egg}$ was capable of inducing $\mathrm{MN}$ in erythrocytes. This effect was further confirmed by PCE/NCE ratio which indicates hematopoietic cell proliferation rate to infer the hampered hematopoiesis or cytotoxicity. However Cd at $60 \mu \mathrm{g}$ per egg has led to a decline in the PCE/NCE ratio, which might be due to the cytotoxic nature of the heavy metal, Cadmium [30].

Apart from MN, poikilocytosis is also observed in the circulating embryonic blood of Cd-treated embryos. In addition to above the high dose groups were presented large undifferentiated erythroid cells i.e. erythroblasts and pro-erythroblasts, which are in definite line by their greater size, lower nucleus-cytoplasm ratio, and circular outline. Exist with an average life span of eight days. According to Wolf and Luepke [30], at this stage of embryonic development, the proerythroblasts and erythroblasts would be observed only after a cytotoxic treatment. Thus, apart from inducing aberrance in the nuclear material, $\mathrm{Cd}$ potentially induces cytotoxic changes which inhibited erythropoiesis and cell differentiation [45]. Similar observations were found in our study in cadmium treated eggs, which showed mn- erythrocytes and

\begin{tabular}{|c|c|c|c|c|c|}
\hline Treatment & Dose /Egg (mg) & Treatment day hr of incubation with $\mathrm{Cd}$ & Day of Sampling & $\%$ MNE (Mean \pm SD) & PCE:NCE \\
\hline \multirow{3}{*}{ Control (saline) } & \multirow{3}{*}{ - } & d $12(24 \mathrm{hr})$ & \multirow{3}{*}{ d 13} & 0 & 0 \\
\hline & & d $11(48 \mathrm{hr})$ & & 0 & 0 \\
\hline & & d 10 (72 hr) & & 0 & 0 \\
\hline \multirow{3}{*}{$\begin{array}{c}\text { Positive control } \\
\text { (Cyclophosphamide) }\end{array}$} & \multirow{3}{*}{$50 \mu \mathrm{g}$} & d $12(24 \mathrm{hr})$ & \multirow{3}{*}{ d 13} & $1.51 \pm 0.03^{a}$ & 1 \\
\hline & & d $11(48 \mathrm{hr})$ & & $5.31 \pm 0.12^{\mathrm{a}}$ & 1 \\
\hline & & d $10(72 \mathrm{hr})$ & & $10.17 \pm 0.10^{d}$ & 1 \\
\hline \multirow{3}{*}{$\mathrm{CdCl}_{2}$} & \multirow{3}{*}{$40 \mu g$} & d $12(24 \mathrm{hr})$ & \multirow{3}{*}{ d 13} & $3.63 \pm 0.19^{b}$ & 1.03 \\
\hline & & d $11(48 \mathrm{hr})$ & & $5.43 \pm 0.28^{\mathrm{a}}$ & 1.05 \\
\hline & & d 10 (72 hr) & & $5.68 \pm 0.31^{\mathrm{a}}$ & 1.054 \\
\hline \multirow{3}{*}{$\mathrm{CdCl}_{2}$} & \multirow{3}{*}{$50 \mu g$} & d $12(24 \mathrm{hr})$ & \multirow{3}{*}{ d 13} & $5.76 \pm 0.31^{\circ}$ & 1.04 \\
\hline & & d $11(48 \mathrm{hr})$ & & $6.81 \pm 0.09^{b}$ & 1.11 \\
\hline & & d 10 (72 hr) & & $7.37 \pm 0.30^{\mathrm{b}}$ & 1.07 \\
\hline \multirow{3}{*}{$\mathrm{CdCl}_{2}$} & \multirow{3}{*}{$60 \mu \mathrm{g}$} & d $12(24 \mathrm{hr})$ & \multirow{3}{*}{ d 13} & $7.76 \pm 0.18^{d}$ & 1.04 \\
\hline & & d $11(48 \mathrm{hr})$ & & $8.60 \pm 0.16^{c}$ & 1.02 \\
\hline & & d 10 (72 hr) & & $8.92 \pm 0.29^{c}$ & 1.01 \\
\hline
\end{tabular}

Values are expressed as mean \pm SD of 6 animals in each group. $p<0.05$ versus the control group; Different letters are significantly different at the level of $p<0.05$. MNE Micronuclei Erythrocytes

Table 1: Micronucleus test performed on 13-day-old chick embryos treated with cyclophosphamide and cadmium at different time intervals. 
Citation: Meena Bai M, Divya K, Haseena Bhanu SK, Sailaja G, Sandhya D, et al. (2014) Evaluation of Genotoxic and Lipid Peroxidation Effect of Cadmium in Developing Chick Embryos. J Environ Anal Toxicol 4: 238. doi: 10.4172/2161-0525.1000238

Page 4 of 6
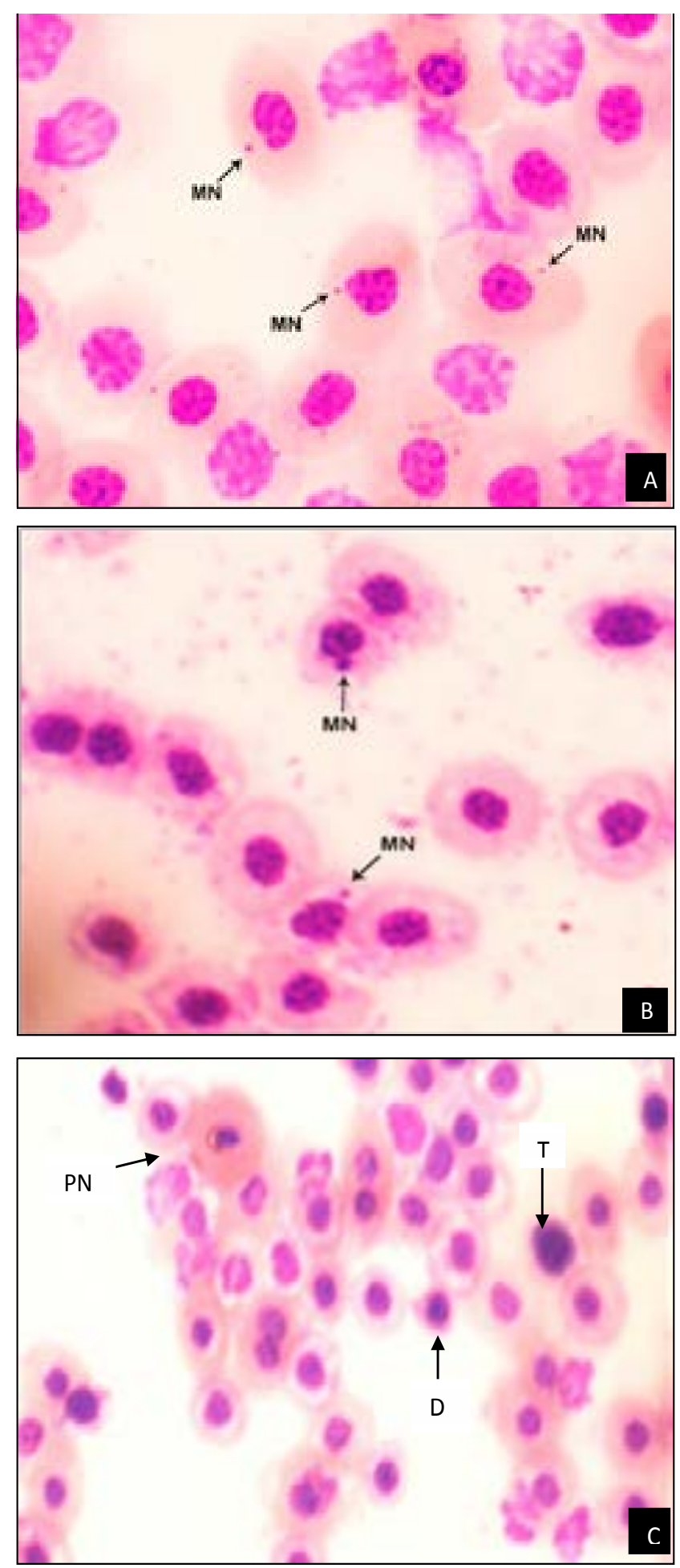

Figure 1: (A), (B) Magnification 100X. NCE with micronucleus (C) Magnification 40X. 1. Dacryocyte or tear drop cell (D) 2. Thrombocyte (T) 3. Primitive NCE with chromosomal aberance (PN).

various other morphological alterations like spindle and pear shaped erythrocytes along with nuclear segmentation (Figure 1B). At this high dose, i.e., $60 \mu \mathrm{g} \mathrm{Cd}$, fragmented nuclei were observed in the embryonic blood smears. Our studies conclude that the Cd treated chick embryos show more of damage to chromosomes in blood cells.

Lipid peroxidation is one of the main manifestations of oxidative damage and has been found to play an important role in the toxicity of many xenobiotics [46]. Malondialdehyde (MDA), a known lipid peroxidation indicator, has been found to increase in the liver and kidneys after cadmium exposure [47]. Cadmium a ubiquitous toxic metal has been recognized as one of the most toxic environmental and industrial pollutants that may induce oxidative damage by disturbing the prooxidant-antioxidant balance in the tissues.

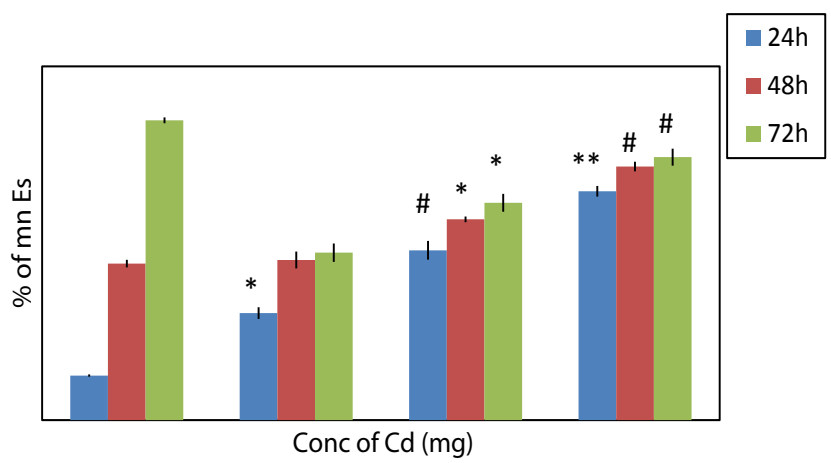

Values are expressed as mean $\pm S D, n=6 . *, * *, \#$ Significant difference from the control group $\left({ }^{*} \mathrm{P}<0.05\right)$. $P C$ indicates positive control; $S D$, standard deviation

Figure 2: Frequency of total micronucleated erythrocytes (MN-Es) in chick embryos treated with positive control (cyclophosphamide) and cadmium at the indicated doses for 24,48 and $72 \mathrm{hr}$.

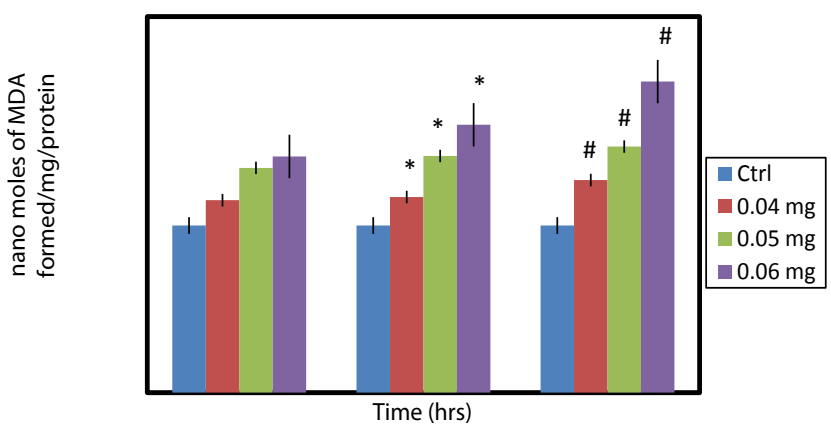

Values are expressed as mean $\pm S D, n=6 . *$, \#Significant difference from the control group $\left({ }^{*} \mathrm{P}<0.05\right)$. MDA indicates malondialdehyde; $S D$, standard deviation

Figure 3: Lipid peroxidation induced by cadmium in $13^{\text {th }}$ day old chick embryonic liver after treatment with increasing doses of cadmium for 24,48 and $72 \mathrm{hr}$.

\begin{tabular}{|c|c|c|c|}
\hline Treatment & $\mathbf{2 4 h}$ & $\mathbf{4 8 h}$ & $\mathbf{7 2 h}$ \\
\hline Control & $39.99 \pm 1.58^{\mathrm{a}}$ & $39.99 \pm 1.58^{\mathrm{a}}$ & $39.99 \pm 1.58^{\mathrm{a}}$ \\
\hline $40 \mu \mathrm{g}$ & $46.06 \pm 1.35^{\mathrm{a}}$ & $46.80 \pm 0.67^{\mathrm{b}}$ & $50.87 \pm 2.72^{\mathrm{c}}$ \\
\hline $50 \mu \mathrm{g}$ & $53.77 \pm 1.58^{\mathrm{a}}$ & $56.63 \pm 0.62^{\mathrm{b}}$ & $58.89 \pm 1.42^{\mathrm{c}}$ \\
\hline $60 \mu \mathrm{gg}$ & $56.50 \pm 1.11^{\mathrm{a}}$ & $64.09 \pm 1.88^{\mathrm{b}}$ & $74.44 \pm 2.34^{\mathrm{c}}$ \\
\hline
\end{tabular}

Units: $\mathrm{nmol}$ of malondialdehyde formed/minute/mg protein. Each value represents the mean $\pm S D(n=6)$. Different letters are significantly different at the level of $p<0.05$ Table 2: Levels of lipid peroxidation measured in the liver of Cadmium treated group in relation to the control group of $13^{\text {th }}$ day chick embryo. 
Citation: Meena Bai M, Divya K, Haseena Bhanu SK, Sailaja G, Sandhya D, et al. (2014) Evaluation of Genotoxic and Lipid Peroxidation Effect of Cadmium in Developing Chick Embryos. J Environ Anal Toxicol 4: 238. doi: 10.4172/2161-0525.1000238

Page 5 of 6

In our study, the administration of different doses of $\mathrm{CdCl}_{2}$ at various time intervals has revealed significant increase of lipid peroxides in liver and also in numerous tissues of chick embryo both in vivo and in vitro [48-50], and therefore it is suggested that $\mathrm{Cd}$ as toxicant may induce oxidative stress by producing either hydroxyl radicals [51], superoxide anions, nitric oxide or hydrogen peroxide [52].

The above result on lipid peroxidation also provides an insight into the role of reactive species in metal-induced toxicity. The "direct" damage due to Cd may involve conformational changes of bio-molecules or alter specific binding sites [53]. On the other hand, "indirect" damage is a consequence of metal driven formation of reactive oxygen/nitrogen species involving superoxide, hydroxyl radicals or nitric oxide, hydrogen peroxide and/or endogenous oxidants [14].

In conclusion the MN Test employed for the genotoxic assessment has indicated that the $\mathrm{Cd}$ shall induce DNA damage along with abnormal cells in the developing chick embryos when treated with concentrations of $40 \mu \mathrm{g}$ to $60 \mu \mathrm{g}$ of $\mathrm{Cd}$. Further our results have indicated that the administration of different concentrations of $\mathrm{Cd}$ at different time intervals interferes with the liver lipid metabolism at cellular levels, suggesting that it could be a mechanism for Cd toxicity in the liver to enhance oxidative stress and subsequently to cause DNA damage and cytotoxicity to chick embryo. Therefore, regular use of heavy metals should be minimized, since our studies have revealed that they are cytotoxic and carcinogenic to all living organisms.

\section{Acknowledgement}

This research was financed by DRDO, New Delhi and UGC OTG, New Delhi.

\section{References}

1. Nriagu JO (1988) A silent epidemic of environmental metal poisoning? Environ Pollut 50: 139-161.

2. Vangronsveld J, Van Assche F, Clijsters H (1995) Reclamation of a bare industrial area contaminated by non-ferrous metals: in situ metal immobilization and revegetation. Environ Pollut 87: 51-59.

3. Anetor $\mathrm{Jl}$ (2012) Rising environmental cadmium levels in developing countries: threat to genome stability and health. Niger J Physiol Sci 27: 103-115.

4. Agency for Toxic Substance and Disease Registry (ATSDR) (2005) Toxicological Profile for Cadmium. Department of Health and Humans Services, Public Health Service, Centers for Disease Control, Atlanta, GA.

5. Bertin G, Averbeck D (2006) Cadmium: cellular effects, modifications of biomolecules, modulation of DNA repair and genotoxic consequences (a review). Biochimie 88: 1549-1559.

6. Thévenod $F$ (2009) Cadmium and cellular signaling cascades: to be or not to be? Toxicol Appl Pharmacol 238: 221-239.

7. Järup L, Berglund M, Elinder CG, Nordberg G, Vahter M (1998) Health effects of cadmium exposure--a review of the literature and a risk estimate. Scand $J$ Work Environ Health 24 Suppl 1: 1-51.

8. Nawrot TS, Van Hecke E, Thijs L, Richart T, Kuznetsova T, et al. (2008) Cadmium-related mortality and long-term secular trends in the cadmium body burden of an environmentally exposed population. Environ Health Perspect 116: $1620-1628$

9. Järup L, Akesson A (2009) Current status of cadmium as an environmenta health problem. Toxicol Appl Pharmacol 238: 201-208.

10. Friberg L, Elinder CG, Kjellstrom $T$ (1992) Environmental health criteria: cadmium. World Health Organization (Geneva) 134: 36-43.

11. Alfvén T, Elinder CG, Järup L (1997) [Cadmium--a pubic health problem?]. Nord Med 112: 331-333

12. Jonah MM, Bhattacharyya MH (1989) Early changes in the tissue distribution of cadmium after oral but not intravenous cadmium exposure. Toxicology 58 : 325-338.
13. Oner G, Sentürk UK, Izgüt-Uysal VN (1996) Role of cadmium-induced lipid peroxidation in the kidney response to atrial natriuretic hormone. Nephron 72 257-262.

14. Valko M, Morris H, Cronin MT (2005) Metals, toxicity and oxidative stress. Curr Med Chem 12: 1161-1208.

15. Lin TY, Huang CH, Kao HH, Liou GG, Yeh SR, et al. (2009) Abi plays an opposing role to Abl in Drosophila axonogenesis and synaptogenesis. Development 136 : 3099-3107.

16. Galan A, Garcia BL, Troyano A, Vilaboa NE, Fernandez C, et al. (2001) The role of intracellular oxidation in death induction (apoptosis and necrosis) in human promonocytic cells treated with stress inducers (cadmium, heat, X- rays). Eur J Cell Biol 80: 312-320.

17. Rikans LE, Yamano $T$ (2000) Mechanisms of cadmium-mediated acute hepatotoxicity. J Biochem Mol Toxicol 14: 110-117.

18. Van Kerkhove E, Pennemans V, Swennen Q (2010) Cadmium and transport of ions and substances across cell membranes and epithelia. Biometals 23 : $823-855$.

19. Chen L, Liu L, Huang S (2008) Cadmium activates the mitogen-activated protein kinase (MAPK) pathway via induction of reactive oxygen species and inhibition of protein phosphatases 2A and 5. Free Radic Biol Med 45: 1035-1044.

20. Watkin RD, Nawrot T, Potts RJ, Hart BA (2003) Mechanisms regulating the cadmium-mediated suppression of Sp1 transcription factor activity in alveolar epithelial cells. Toxicology 184: 157-178

21. Tappel AL (1973) Lipid peroxidation damage to cell components. Fed Proc 32 1870-1874.

22. Benedetti A, Comporti M, Esterbauer H (1980) Identification of 4-hydroxynonena as a cytotoxic product originating from the peroxidation of liver microsomal lipids. Biochim Biophys Acta 620: 281-296.

23. Kara H, Karatas F, Canatan H, Servi K (2005) Effects of exogenous metallothionein on acute cadmium toxicity in rats. Biol Trace Elem Res 104 223-232.

24. Li M, Kondo T, Zhao QL, Li FJ, Tanabe K, et al. (2000) Apoptosis induced by cadmium in human lymphoma U937 cells through Ca2+-calpain and caspasemitochondria- dependent pathways. J Biol Chem 275: 39702-39709.

25. Kondoh M, Araragi S, Sato K, Higashimoto M, Takiguchi M, et al. (2002) Cadmium induces apoptosis partly via caspase-9 activation in HL-60 cells. Toxicology 170: 111-117.

26. Martinon F, Mayor A, Tschopp J (2009) The inflammasomes: guardians of the body. Annu Rev Immunol 27: 229-265

27. Romanoff A (1960) The Avian Embryo, Structural and Functional Development New York: McMillan.

28. Sheikh RB, Thyagaraju K (2010) Effect of acrylamide on chick embryo live GSTs. Mediterranian J Nutrition and Metabolism 3: 31-38.

29. Norppa H, Renzi L, Lindholm C (1993) Detection of whole chromosomes in micronuclei of cytokinesis-blocked human lymphocytes by antikinetochore staining and in situ hybridization. Mutagenesis 8: 519-525.

30. Wolf T, Niehaus-Rolf C, Luepke NP (2002) Some new methodological aspects of the hen's egg test for micronucleus induction (HET-MN). Mutat Res 514: $59-76$

31. Saleh K, Sarhan MAA (2007) Clastogenic Analysis of Chicken Farms Using Micronucleus Test in Peripheral Blood. Journal of Applied Sciences Research 3: $1646-1649$

32. larmarcovai G, Bonassi S, Botta A, Baan RA, Orsière T (2008) Genetic polymorphisms and micronucleus formation: a review of the literature. Mutat Res 658: 215-233

33. Miller BM, Pujadas E, Gocke E (1995) Evaluation of the micronucleus test in vitro using Chinese hamster cells: results of four chemicals weakly positive in the in vivo micronucleus test. Environ Mol Mutagen 26: 240-247.

34. Garriott ML, Phelps JB, Hoffman WP (2002) A Protocol for the in vitro Micronucleus Test-I. Contributions to the Development of a Protocol Suitable for Regulatory Submissions from an Examination of 16 Chemicals with Different Mechanisms of Action and Different Levels of Activity. Mutation Research 517 123-134. 
Citation: Meena Bai M, Divya K, Haseena Bhanu SK, Sailaja G, Sandhya D, et al. (2014) Evaluation of Genotoxic and Lipid Peroxidation Effect of Cadmium in Developing Chick Embryos. J Environ Anal Toxicol 4: 238. doi: 10.4172/2161-0525.1000238

35. Heddle JA (1990) Micronuclei in vivo. Prog Clin Biol Res 340B: 185-194.

36. Saleh K, Zeytinoglu H (2001) Micronucleus Test in Peripheral Erythrocytes of Rana Ridipunda as an Indicator of Environmental Pollution. Anadolu University Journal of Science and Technology 2: 77-82.

37. Blankenship AL, Hilscherova K, Nie M, Coady KK, Villalobos SA, et al. (2003) Mechanisms of TCDD-induced abnormalities and embryo lethality in white leghorn chickens. Comp Biochem Physiol C Toxicol Pharmacol 136: 47-62.

38. Wolf T, Luepke NP (1997) Formation of micronuclei in incubated hen's eggs as a measure of genotoxicity. Mutat Res 394: 163-175.

39. Chaubey RC, Bhilwade HN, Joshi BN, Chauhan PS (1993) Studies on the migration of micronucleated erythrocytes from bone marrow to the peripheral blood in irradiated Swiss mice. Int J Radiat Biol 63: 239-245.

40. Lucas AM, Jamroz C (1961) Atlas of Avian Hematology. Washington, DC: United States, Department of Agriculture, U.S. Government Printing Office: $1-133$.

41. Okhawa H, Ohishi N, Yagi K (1979) Assay for lipid peroxides in animal tissues by thiobarbituric acid reaction. Anal. Biochem 95: 351-358.

42. LOWRY OH, ROSEBROUGH NJ, FARR AL, RANDALL RJ (1951) Protein measurement with the Folin phenol reagent. J Biol Chem 193: 265-275.

43. Patten BM (1920) The Early Embryology of the Chick. Philadelphia: P. Blakiston's Son and Co.

44. Bolognesi C, Perrone E, Roggieri P, Pampanin DM, Sciutto A (2006) Assessment of micronuclei induction in peripheral erythrocytes of fish exposed to xenobiotics under controlled conditions. Aquat Toxicol 78 Suppl 1: S93-98.
45. Sinclair JF, Sinclair PR (1992) Avian cytochrome p450. In Schenkmann J, Greim $\mathrm{H}$ (Eds), Hand book of Experimental pharmacology, Springer, Heidelberg 105: 259-277.

46. Anane R, Creppy EE (2001) Lipid peroxidation as pathway of aluminium cytotoxicity in human skin fibroblast cultures: prevention by superoxide dismutase+catalase and vitamins E and C. Hum Exp Toxicol 20: 477-481.

47. Shaikh ZA, Vu TT, Zaman K (1999) Oxidative stress as a mechanism of chronic cadmium-induced hepatotoxicity and renal toxicity and protection by antioxidants. Toxicol Appl Pharmacol 154: 256-263.

48. Casalino E, Sblano C, Landriscina C (1997) Enzyme activity alteration by cadmium administration to rats: the possibility of iron involvement in lipid peroxidation. Arch Biochem Biophys 346: 171-179.

49. Sarkar S, Yadav P, Bhatnagar D (1997) Cadmium-induced lipid peroxidation and the antioxidant system in rat erythrocytes: the role of antioxidants. J Trace Elem Med Biol 11: 8-13.

50. Tandon SK, Singh S, Prasad S, Khandekar K, Dwivedi VK, et al. (2003) Reversal of cadmium induced oxidative stress by chelating agent, antioxidant or their combination in rat. Toxicol Lett 145: 211-217.

51. O'Brien P, Salacinski HJ (1998) Evidence that the reactions of cadmium in the presence of metallothionein can produce hydroxyl radicals. Arch Toxicol 72 $690-700$.

52. Waisberg M, Joseph P, Hale B, Beyersmann D (2003) Molecular and cellular mechanisms of cadmium carcinogenesis. Toxicology 192: 95-117.

53. Arroyo VS, Flores KM, Ortiz LB, Gomez-Quiroz LE, Gutierrez-Ruiz MC (2012) Liver and cadmium toxicity. J Drug Metab Toxicol S5: 001. 